\title{
First records of non-native species Malaysian prawn Macrobrachium rosenbergii (Decapoda: Palaemonidae) in an important South American hydrographic system
}

Primeiro registro da espécie não nativa camarão da Malásia Macrobrachium rosenbergii (Decapoda: Palaemonidae) em um importante sistema hidrográfico sul-americano

\author{
Thiago Augusto da Silva ${ }^{*}$ (D), Eduardo Luís Cupertino Ballester ${ }^{1,2}$ (D) \\ and Almir Manoel Cunico ${ }^{1,3}$
}

${ }^{1}$ Programa de Pós-graduação em Aquicultura e Desenvolvimento Sustentável, Universidade Federal do Paraná - UFPR, Setor Palotina, Rua Pioneiro, 2153, CEP 85950-000, Palotina, PR, Brasil

${ }^{2}$ Laboratório de Carcinicultura, Universidade Federal do Paraná - UFPR, Setor Palotina, Rua Pioneiro, 2153, CEP 85950-000, Palotina, PR, Brasil

${ }^{3}$ Laboratório de Ecologia, Pesca e Ictiologia, Universidade Federal do Paraná - UFPR, Setor Palotina, Rua Pioneiro, 2153, CEP 85950-000, Palotina, PR, Brasil

*e-mail: thiagoaugustosilva30@gmail.com

Cite as: Silva, T.A., Ballester, E.L.C. and Cunico, A.M. First records of non-native species Malaysian prawn Macrobrachium rosenbergii (Decapoda: Palaemonidae) in an important South American hydrographic system. Acta Limnologica Brasiliensia, 2020, vol. 32, e25.

Abstract: Aim: The objective of this work is to record the occurrence of non-native species Macrobrachiun rosenbergii in water bodies of the Piquiri River basin, State of Paraná, Brazil, an important South American hydrographic system. Methods: Samples were obtained from October 2015 to June 2016 and from September 2017 to September 2018, using traps and electric fishing equipment (portable alternating current generator, $2.5 \mathrm{~kW}, 400 \mathrm{~V}, 2 \mathrm{~A}$ ) in the Piquiri River and two tributaries. Results: 16 M. rosenbergii specimens were caught, 11 females and 5 males. Conclusions: Our results indicated the introduction of the species $M$. rosenbergii into the Piquiri River basin by aquaculture activity. The constant insertion of new specimens by the productive sector may, in the short term, maintain populations with large number of individuals, causing potential damage to the native biodiversity.

Keywords: aquaculture; biological invasion; crustaceans; propagule pressure; species introduction.

Resumo: Objetivo: Este trabalho tem como objetivo registrar a ocorrência da espécie não nativa Macrobrachiun rosenbergii na bacia hidrográfica do rio Piquiri, Estado do Paraná, Brasil, um importante sistema hidrográfico Sul-Americano. Métodos: As amostras foram coletadas de outubro de 2015 a junho de 2016 e de setembro de 2017 a setembro de 2018, utilizando armadilhas e equipamento elétrico de pesca (gerador de corrente alternada portátil, $2,5 \mathrm{~kW}, 400 \mathrm{~V}, 2 \mathrm{~A}$ ) no rio Piquiri e dois afluentes. Resultados: 16 espécimes de $M$. rosenbergii foram capturados, 11 fêmeas e 5 machos. Conclusóes: Nossos resultados indicaram a introdução da espécie M. rosenbergii na bacia do rio Piquiri pela atividade de aquicultura. A constante inserção de novos espécimes pela aquicultura pode manter populaçóes com elevado número de indivíduos, ocasionando potenciais danos à biodiversidade nativa.

Palavras-chave: aquicultura; invasão biológica; crustáceos; pressão de propágulos; introdução de espécies. 
Originally occurring in South and Southeast Asia, parts of Oceania, and some Pacific islands (New, 2000), the Malaysian prawn, Macrobrachium rosenbergii (de Man, 1879), has aroused the interest of aquaculture farmers and currently, it has been introduced in over 40 countries (Iketani et al., 2011). In Brazil, due to the expansion of continental aquaculture, especially the production of Nile tilapia (Oreochromis niloticus) (Linnaeus, 1758), and the viability of polyculture production including prawns, there is a warning signal for new species introductions in Brazilian inland waters. In this scenario, the State of Paraná stands out as the main vector of new introductions, given that it is the largest tilapia producer in Brazil (IBGE, 2017) and a precursor in the implementation of systems for farming fish and prawns together in the western region of the state (Dutra et al., 2015). This way, the present study describes the first records of the species $M$. rosenbergii in water bodies of the Piquiri River basin, State of Paraná, Brazil.
Samples were obtained monthly from October 2015 to June 2016 in the Piquiri River and its tributary São Pedro Stream, and quarterly from September 2017 to September 2018 in Pioneiro Stream (Figure 1). The selection of these environments was based on the presence of aquaculture farms (i.e., freshwater prawn farming) with production of the species $M$. rosenbergii.

Due to the environmental characteristics of the sampled sites (great depth and flow), captures were performed using traps with three different funnel sizes to minimise specimen size selectivity. The traps were arranged equidistantly, in sets of three units, in the water outlets of the cultivation ponds, as well as in the water bodies receiving the effluent water. For the samplings performed in Pioneiro Stream, we used electric fishing equipment (portable alternating current generator, $2.5 \mathrm{~kW}, 400 \mathrm{~V}, 2 \mathrm{~A}$ ) with three successive captures and constant catch per unit effort (CPUE) in segments of approximately 50 metres delimited by multifilament nets, at three sampling

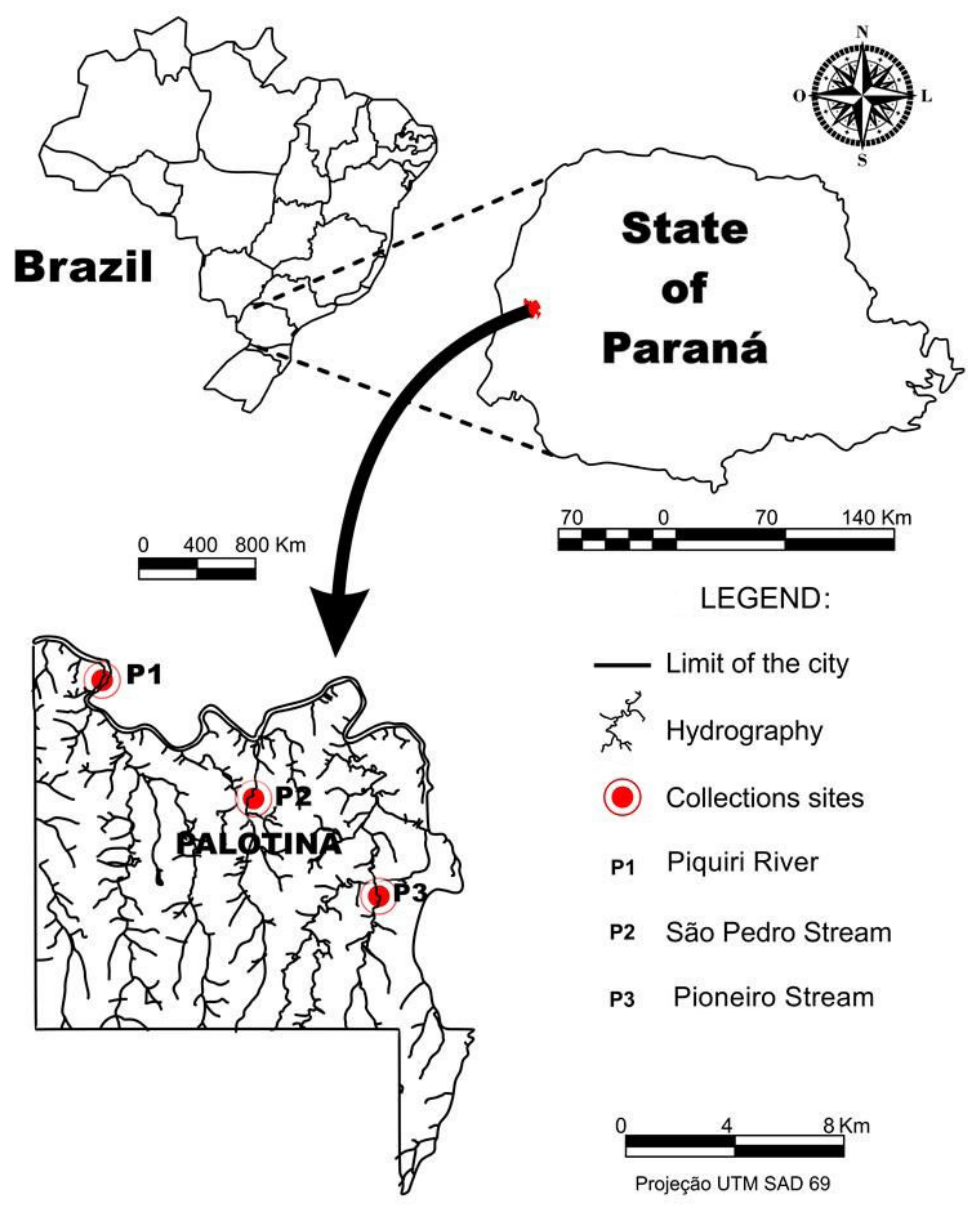

Figure 1. Collection sites of Malaysian prawn Macrobrachium rosenbergii along the Piquiri River basin municipality of Palotina, State of Paraná, southern Brazil. 
sites (headwaters, middle section, and mouth of the stream).

The collected individuals were taken to the Laboratory of Ecology, Fishing and Ichthyology, Federal University of Paraná, Palotina Sector, for taxonomic identification following specialised identification keys (Dore \& Frimodt, 1987; Sampaio et al., 2009). All specimens collected remain deposited in the Crustacean Collection of the Capão da Imbuia Natural History Museum, Curitiba, State of Paraná, Brazil (MHNCI 5556; 5557; 5558; 5561; 8702).

In December 2015, we caught eight female specimens of $M$. rosenbergii in the Piquiri River and one male specimen in São Pedro Stream. In July 2018, we caught seven specimens in Pioneiro Stream, four males and three females (Table 1).
The comparison with the specialised literature (New et al., 2010; Pinheiro \& Hebling, 1998), as well as the direct comparison with specimens from cultivated areas, allowed confirming the capture of the species (Figure 2a). The species $M$. rosenbergit differs from the other species of the genus by its long and upwardly curved rostrum, presenting between eight and fifteen dorsal teeth, and six to sixteen ventral teeth (Figure 2b). The chelipedal carpus is distinctly larger than the merus, and the telson tip reaches far beyond the longer posterior spines (Figure 2c).

The introduction of a new cultivated species observed throughout the present study reflects a common situation in developing countries. The demand for rapid economic growth encourages the use of non-native species with globally consolidated technology systems to
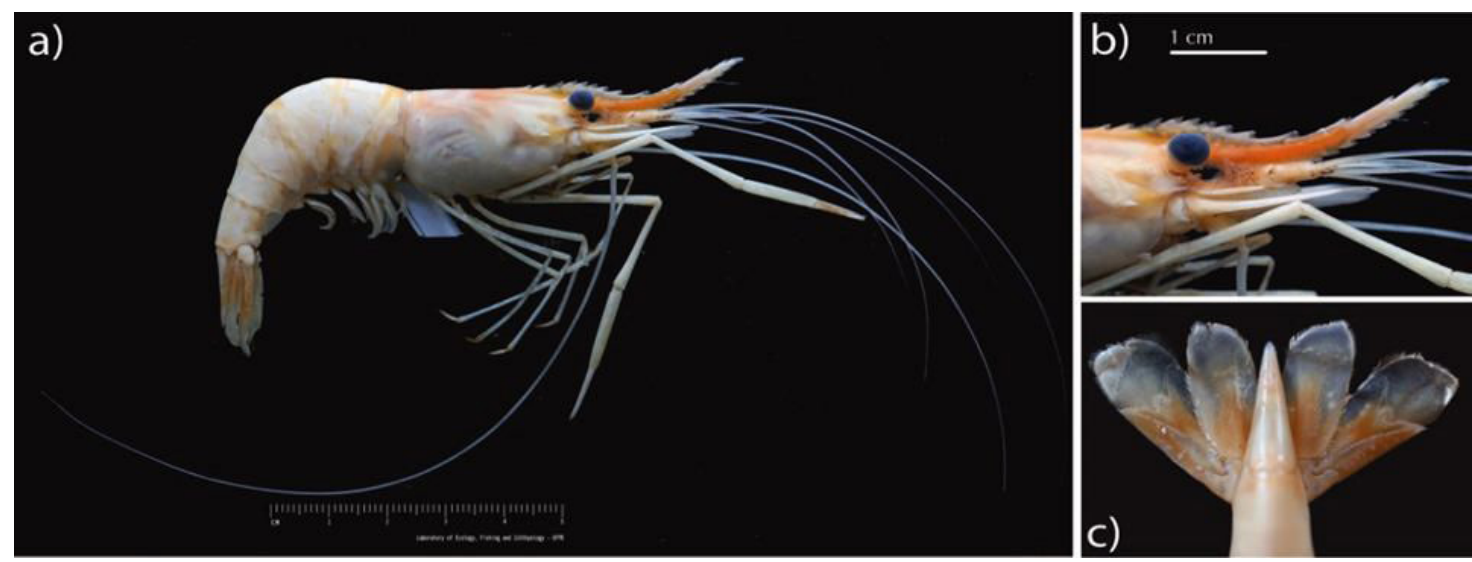

Figure 2. (a) Captured female specimen of Malaysian prawn Macrobrachium rosenbergii; (b) Detailing of the long and upwardly curved rostrum; (c) Detailing of the telson reaching far beyond the longer posterior spines.

Table 1. Identification number, deposit record at the Capão da Imbuia Natural History Museum (MHNCI), location, capture date, sex, carapace length $(\mathrm{Cl})$, and weight in grams of Malaysian prawn Macrobrachium rosenbergii specimens.

\begin{tabular}{|c|c|c|c|c|c|c|c|c|}
\hline $\begin{array}{c}\text { Indentification } \\
\text { Number }\end{array}$ & $\mathrm{MHNCl}$ & Location & Latitude S & Longitude 0 & $\begin{array}{l}\text { Capture } \\
\text { Date }\end{array}$ & Sex & $\mathrm{Cl}$ & Weight (g) \\
\hline 46 & 5556 & Piquiri River & $24^{\circ} 08^{\prime} 46.4^{\prime \prime}$ & $53^{\circ} 54^{\prime} 51.5^{\prime \prime}$ & $\mathrm{dec} / 15$ & Female & 2.8 & 1.7 \\
\hline 54 & 5556 & Piquiri River & $24^{\circ} 08^{\prime} 46.4^{\prime \prime}$ & $53^{\circ} 54^{\prime} 51.5^{\prime \prime}$ & $\mathrm{dec} / 15$ & Female & 1.7 & 0.46 \\
\hline 56 & 5556 & Piquiri River & $24^{\circ} 08^{\prime} 46.4^{\prime \prime}$ & $53^{\circ} 54^{\prime} 51.5^{\prime \prime}$ & $\mathrm{dec} / 15$ & Female & 2.2 & 0.74 \\
\hline 59 & 5556 & Piquiri River & $24^{\circ} 08^{\prime} 46.4^{\prime \prime}$ & $53^{\circ} 54^{\prime} 51.5^{\prime \prime}$ & $\mathrm{dec} / 15$ & Female & 2 & 0.57 \\
\hline 68 & 5556 & Piquiri River & $24^{\circ} 08^{\prime} 46.4^{\prime \prime}$ & $53^{\circ} 54^{\prime} 51.5^{\prime \prime}$ & $\mathrm{dec} / 15$ & Female & 1.8 & 0.34 \\
\hline 51 & 5561 & Piquiri River & $24^{\circ} 08^{\prime} 46.4^{\prime \prime}$ & $53^{\circ} 54^{\prime} 51.5^{\prime \prime}$ & $\mathrm{dec} / 15$ & Female & 1.7 & 0.57 \\
\hline 70 & 5557 & Piquiri River & $24^{\circ} 08^{\prime} 46.4^{\prime \prime}$ & $53^{\circ} 54^{\prime} 51.5^{\prime \prime}$ & $\mathrm{dec} / 15$ & Female & 2.3 & 0.2 \\
\hline 72 & 5557 & Piquiri River & $24^{\circ} 08^{\prime} 46.4^{\prime \prime}$ & $53^{\circ} 54^{\prime} 51.5^{\prime \prime}$ & $\mathrm{dec} / 15$ & Female & 1.7 & 0.56 \\
\hline 23 & 5558 & São Pedro Stream & $24^{\circ} 18^{\prime} 13^{\prime \prime}$ & $53^{\circ} 43^{\prime} 46^{\prime \prime}$ & jun/16 & Male & 5.2 & 7.26 \\
\hline 2 & 8702 & Pioneiro River & $24^{\circ} 18^{\prime} 37^{\prime \prime}$ & $53^{\circ} 48^{\prime} 53.1^{\prime \prime}$ & jun/18 & Female & 2.6 & 9.37 \\
\hline 3 & 8702 & Pioneiro River & $24^{\circ} 18^{\prime} 37^{\prime \prime}$ & $53^{\circ} 48^{\prime} 53.1^{\prime \prime}$ & jun/18 & Male & 3.1 & 2.5 \\
\hline 17 & 8702 & Pioneiro River & $24^{\circ} 18^{\prime} 37^{\prime \prime}$ & $53^{\circ} 48^{\prime} 53.1^{\prime \prime}$ & jun/18 & Male & 7.2 & 24.14 \\
\hline 18 & 8702 & Pioneiro River & $24^{\circ} 18^{\prime} 37^{\prime \prime}$ & $53^{\circ} 48^{\prime} 53.1^{\prime \prime}$ & jun/18 & Male & 5.4 & 12.97 \\
\hline 19 & 8702 & Pioneiro River & $24^{\circ} 18^{\prime} 37^{\prime \prime}$ & $53^{\circ} 48^{\prime} 53.1^{\prime \prime}$ & jun/18 & Female & 5 & 10.46 \\
\hline 36 & 8702 & Pioneiro River & $24^{\circ} 18^{\prime} 37^{\prime \prime}$ & $53^{\circ} 48^{\prime} 53.1^{\prime \prime}$ & jun/18 & Female & 4.2 & 4.96 \\
\hline 750 & 8702 & Pioneiro River & 2418’37" & $53^{\circ} 48^{\prime} 53.1^{\prime \prime}$ & jun/18 & Male & 15.4 & 29.43 \\
\hline
\end{tabular}


the detriment of native species, thus increasing the risks of biological introductions and invasions (Pelicice et al., 2017). With respect to M. Rosenbergii, information about its potential negative impact on biodiversity-although concentrated in estuarine regions-has indicated the high risk of invasion (Iketani et al., 2016). It is well known that the species $M$. rosenbergii inhabits tropical rivers, lakes, and reservoirs; however, it needs access to adjacent areas of brackish water, which is essential for achieving complete larval development and reproductive cycle (Pinheiro \& Hebling, 1998). However, even though they are unable to naturally complete their reproductive cycle within the Piquiri River basin, due to the lack of connectivity with estuarine regions, the constant insertion of new specimens by the productive sector may (propagule pressure), in the short term, artificially maintain populations with large number of individuals. This fact would result in the recruitment of new specimens, thus causing potential damage to the native biodiversity. In this way, we highlight that some actions are necessary to prevent escapes like education of freshwater prawn farmers to understand the nonnative species concept and their environmental risks, adoption of structural measures to minimize the escape of non-native species from aquaculture facilities (e.g. screens, covers, control structures and containment ponds), as well as improvement of inspections and monitoring by Brazilian Enviromental Agencies (see Nobile et al., 2019).

\section{Acknowledgements}

The authors are thankful to the researchers of the Ecology, Fisheries and Ichthyology Laboratory of the Federal University of Paraná for their contributions throughout the research. We are also thankful to the Capão da Imbuia National Museum, especially to Dr. Odete Lopez Lopes and Dr. Setuko Masunari for their help in the taxonomic identification of the collected material. T.A.S is thankful to the Coordination for the Improvement of Higher Education Personnel (CAPES) for the financial support. Finally, we are thankful to anonymous reviewers for their helpful suggestions. Thiago Augusto da Silva (Financing Code 001) thank the funding from the Coordination for the Improvement of Higher Education Personnel (CAPES) for the scholarships. Ballester E.L.C. (PQ process: 307206/2017-3) thank the National Council for Scientific and Technological Development (CNPq) for the Research Productivity Grant.

\section{References}

DORE, I. and FRIMODT, C. An illustrated guide to shrimp of the world. New York: Osprey Books, 1987.

DUTRA, F.M., BRAZÃO, C.C., HELDT, A. and BALLESTER, E.L.C. Carcinicultura: relato de experiência no oeste do Paraná. Caminho Aberto: Revista de Extensão do IFSC, 2015, 1(3), 117-122. http://dx.doi.org/10.35700/ca.2015.ano2n3.p117122.1790.

IKETANI, G., AVIZ, M.A.B., MACIEL, C., VALENTI, W., SCHNEIDER, H. and SAMPAIO, I. Successful invasion of the Amazon Coast by the giant river prawn, Macrobrachium rosenbergii: evidence of a reproductively viable population. Aquatic Invasions, 2016, 11(3), 277-286. http://dx.doi.org/10.3391/ ai.2016.11.3.06.

IKETANI, G., PIMENTEL, L., SILVA-OLIVEIRA, G., MACIEL, C., VALENTI, W., SCHNEIDER, $\mathrm{H}$. and SAMPAIO, I. The history of the introduction of the giant river prawn, Macrobrachium cf. rosenbergii (Decapoda, Palaemonidae), in Brazil: New insights from molecular data. Genetics and Molecular Biology, 2011, 34(1), 142-151. http://dx.doi.org/10.1590/ S1415-47572010005000115. PMid:21637558.

INSTITUTO BRASILEIRO DE GEOGRAFIA E ESTATÍsTICA - IBGE. Produção pecuária municipal. Rio de Janeiro: IBGE, 2017.

NEW, M.B. History and global status of freshwater prawn farming. In: M.B. NEW and W.C. VALENTI, eds. Freshwater prawn culture: the farming of Macrobrachium rosenbergii. London: Blackwell Science, 2000. pp 1-10. http://dx.doi. org/10.1002/9780470999554.ch1.

NEW, M.B., D’ABRAMO, L.R., VALENTI, W. and INGHOLKA, S. Sustainability of freshwater prawn culture. In: M.B. NEW, W. VALENTI, J.H. TIDWELL, L.R. D'ABRAMO and M.N. KUTTY, eds. Freshwater prawns: biology and farming. 1st ed. Ames: Blackwell Publishing, 2010, pp. 524-530.

NOBILE, A.B., CUNICO, A.M., VITUlE, J.R.S., QUEIROZ, J., VIDOTTO-MAGNONI, A.P., GARCIA, D.A.Z., ORSI, M.L., LIMA, F.P., ACOSTA, A.A., SILVA, R.J., PRADO, F.D., PORTO-FORESTI, F., BRANDÃO, H., FORESTI, F., OLIVEIRA, C. and RAMOS, I.P. Status and recommendations for sustainable freshwater aquaculture in Brazil. Reviews in Aquaculture, 2019, 11, 1-23. http://dx.doi.org/10.1111/raq.12393.

PELICICE, F.M., AZEVEDO-SANTOS, V.M., VITULE, J.R., ORSI, M.L., LIMA JUNIOR, D.P.., MAGALHÁES, A.L., POMPEU, P.S., PETRERE JUNIOR, M. and AGOSTINHO, A.A. Neotropical freshwater fishes imperilled by unsustainable policies. Fish and Fisheries, 2017, 18(6), 1119-1133. http:// dx.doi.org/10.1111/faf.12228. 
PINHEIRO, M.A.A. and HEBLING, N.J. Biologia de Macrobrachium rosenbergii (De Man, 1879). In: W.C. VALENTI, ed. Carcinicultura de água doce: tecnologia para produção de camarōes. Brasília: IBAMA, 1998, pp. 21-46.

SAMPAIO, S.R., NAGATA, J.K., LOPES, O.L. and MASUNARI, S. Camarōes de águas continentais (Crustacea, Caridea) da Bacia do Atlântico oriental paranaense, com chave de identificação tabular. Acta
Biológica Paranaense, 2009, 38(1-2), 11-34. http:// dx.doi.org/10.5380/abpr.v38i0.15974.

Received: 30 September 2019 Accepted: 29 July 2020

Associate Editors: Gustavo Henrique Gonzaga da Silva, Antonio Fernando Monteiro Camargo. 